\title{
Characterization of Peach TFL1 and Comparison with $F$ T/TFL1 Gene Families of the Rosaceae
}

\author{
Yihua Chen and Peng Jiang \\ Horticulture Department, University of Georgia, Athens, GA 30602 \\ Shivegowda Thammannagowda and Haiying Liang \\ Department of Genetics and Biochemistry, Clemson University, Clemson, SC 29634
}

H. Dayton Wilde ${ }^{1}$
Horticulture Department and Institute of Plant Breeding, Genetics and Genomics, University of
Georgia, 1111 Plant Sciences, Athens, GA 30602

Additional Index words. Prunus persica, gene expression, phylogenetics, ornamental, floral induction

Abstract. We investigated the FT/TFL1 family of peach (Prunus persica), a gene family that regulates floral induction in annual and perennial plants. The peach terminal flower 1 gene (PpTFL1) was expressed in a developmental and tissue-specific pattern that, overall, was similar to that of $T F L 1$ orthologs in other woody Rosaceae species. Consistent with a role as a floral inhibitor, ectopic expression of PpTFL1 in arabidopsis (Arabidopsis thaliana) delayed flowering and prolonged vegetative growth. Other members of the peach $F T / T F L 1$ family were identified from the sequenced genome, including orthologs of flowering locus $T$, centroradialis, brother of ft, and mother of ft and $t$ fl. Sequence analysis found that peach $F T / T F L 1$ family members were more similar to orthologous genes across the Rosaceae than to each other. Together these results suggest that information on genes that regulate flowering in peach could be applied to other Rosaceae species, particularly ornamentals.

Genes that regulate the transition from vegetative to reproductive development are important to plant domestication and improvement. In crops such as tomato (Solanum lycopersicum) and soybean (Glycine max), cultivars have been developed with a determinate growth habit in which shoots are committed to flowering. Determinate growth in tomato and soybean is a recessive trait controlled by the loci self-pruning (sp) and determinate 1 (dt1), respectively (Woodworth, 1932; Yeager, 1927). $S p$ and $d t 1$ have been identified as orthologs of the arabidopsis gene TFL1 (Pnueli et al., 1998; Tian et al., 2010). The protein encoded by TFL1 acts a repressor to maintain vegetative growth, and homozygous mutations of AtTFL1, GmTFL1, and SISP lead to reduced vegetative growth and early terminal differentiation. In an herbaceous perennial, woodland strawberry (Fragaria vesca), a mutation in FvTFL1 prevents long-day suppression of flowering, resulting in continuous blooms (Iwata et al., 2012; Koskela et al., 2012). Other genes that regulate the transition to flowering include flowering locus $T(F T)$, which encodes a major component of florigen (Turck et al., 2008). FT and TFL1 have closely related sequences but opposing functions (Hanzawa et al., 2005).

In most woody plants, flowering is repressed during the juvenile phase and then regulated annually in the adult phase. TFL1 is integral to the control of both processes. The juvenile phase of apple (Malus $\times$ domestica), pear (Pyrus communis), and hybrid poplar (Populus tremula $\times a l b a$ ) was shortened by years when the expression of TFL1 orthologs was suppressed (Frieman et al., 2011; Kotoda et al., 2006; Mohamed et al., 2010). The annual flowering habit of rose (Rosa sp.) has been altered by centuries of breeding for the recessive locus recurrent

Received for publication 15 Aug. 2012. Accepted for publication 7 Oct. 2012. We are grateful to Tetyana Zhebentyayeva for providing peach floral and vegetative buds.

${ }^{1}$ Corresponding author. E-mail: dwilde@uga.edu. blooming (Iwata et al., 2012). $R b$ was recently identified as a TFL1 ortholog and rose cultivars with low RoTFL1 expression bloom repetitively instead of annually (Iwata et al., 2012; Wang et al., 2011b). Remontant rose cultivars also have a reduced juvenile phase, and apple and pear with suppressed TFL1 had repetitive blooms on new growth (Frieman et al., 2011; Iwata et al., 2012; Kotoda et al., 2006).

Genes such as TFL1 that regulate shoot meristem identity are targets for the improvement of woody ornamental plants by molecular breeding. Repetitive blooming is a valuable trait for woody ornamentals as shown by the commercial success of remontant azalea (e.g., Rhododendron sp. 'Encore'), hydrangea (e.g., Hydrangea macrophylla 'Endless Summer'), and rose (e.g., Rosa hybrida 'Knockout'). Shoot meristem identity in woody plants is regulated by gene products interacting in response to environmental or endogenous cues (reviewed in Benlloch et al., 2007; Wilkie et al., 2008). TFL1, for example, inhibits the transcription factor FD from turning on other floral regulatory genes (Hanano and Goto, 2011). In addition to genetic control, shoot phase change is further regulated through histone modification, DNA methylation, and microRNA production (Angel et al., 2011; Wang et al., 2011a; Yaish et al., 2011). As a result of their profound effect on the switch to determinate growth, TFL1 and FT are genes in this complex regulatory network that could give insight into the control of flowering patterns in woody ornamental plants.

We investigated TFL1 in peach, which has potential as a genetic model for woody ornamental plants for several reasons: 1$)$ it has a small, diploid genome $(230 \mathrm{Mb})$ that has been sequenced; 2) complete, self-fertile flowers are produced after a relatively short juvenile stage of two to three years; and 3) several floral regulatory genes have been characterized, including peach orthologs of agamous, apetalal, leafy, plena, seedstick, sepallata, and short vegetative phase (An and $\mathrm{Li}$, 2008; Arús et al., 2012; Martin et al., 2006; Tadiello et al., 
2009; Tani et al., 2009; Xu et al., 2008; Yamane et al., 2011; Zhang et al., 2008). The genomic sequence of PpTFL1 of peach has been identified (Liang et al., 2010) and the allelic diversity of PpTFL1 was found to be low among cultivars bred for the eastern United States (Chen and Wilde, 2011).

We examined PpTFL1 function by characterizing its native expression in peach and the effect of its ectopic expression in arabidopsis. We identified $P p F T$ and related gene family members and compared the FT/TFL1 family of peach with that of other species of Rosaceae. These studies allowed us to examine the reliability of applying genetic information from peach to other woody rosaceous plants.

\section{Materials and Methods}

Plant materials and NuCleic aCID Preparation. Leaves, floral organs, and fruit were obtained from peach trees ('Redhaven') grown at the University of Georgia Horticulture Farm (Watkinsville, GA). Shoot tip samples were collected in May and August and dormant buds (floral and vegetative) were collected in November and March. Seedling material was obtained from two-month-old plants maintained in a growth room $\left(22^{\circ} \mathrm{C}, 16 \mathrm{~h}\right.$ light/8 h dark). Total RNA was isolated from peach and arabidopsis tissues using the RNeasy Plant Mini Kit (Qiagen, Germantown, MD). After treatment with RNase-free DNase, RNA was quantified with a spectrophotometer (NanoDrop 8000; Thermo Scientific, Wilmington, DE) and $1 \mu \mathrm{g}$ RNA was used in each reverse transcription reaction. cDNA synthesis was performed with M-MLV reverse transcriptase and oligo $\mathrm{d}(\mathrm{T})_{15}$ primers as described by Chen et al. (2003). The cDNA from peach and arabidopsis was diluted 1:25 and 1:100, respectively, for polymerase chain reaction (PCR) analysis. Plant genomic DNA was isolated using the DNeasy Plant Mini Kit (Qiagen).

REVERSE TRANSCRIPTION-POLYMERASE CHAIN REACTION PRIMERS AND REACTION CONDITIONS. The PpTFL1 genomic sequence (GenBank accession GU591895) was used to design PCR primers (Fig. 1). The primers TE1F (5'-CACTCCTCCTC ATTCTCTCTGTCTC-3') and TE4R (5'- GAGGAGCTTTG GGGTTTTGGGTAG-3') were designed from 5' and 3' UTR sequences, respectively, for gene-specific amplification of the complete PpTFL1 coding sequence. Amplification of exons 3 and 4 was carried out with TE3RTF $\left(5^{\prime}\right.$-GACAGATATTCCG GGCACCACAG-3') and TE4RTR (5'-ACGGCAGCGACAG GAGGACC-3') in peach and with TE3RTF and TE4R in transgenic arabidopsis. Glyceraldehyde phosphate dehydrogenase (GAPDH) was used as a reference gene (Tong et al., 2009) and

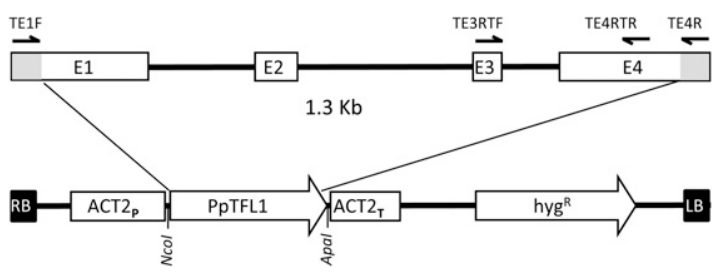

Fig. 1. Polymerase chain reaction (PCR) primers and gene construct for PpTFL1 analysis. PCR primer locations are shown above exons (E) on the PpTFL1 gene diagram. For transformation, the genomic sequence was subcloned between arabidopsis actin2 promoter and terminator sequences inserted into the T-DNA of pCAMBIA1300. Gray boxes show untranslated regions of exons; $\mathrm{RB}$ and $\mathrm{LB}=$ right and left T-DNA borders; hyg ${ }^{\mathrm{R}}=$ hygromycinresistance marker CaMV35SP:HPT. was amplified by the primers GAPDHF2 (5'-TGAGGGCAA GCTGAAGGGTATCTT-3') and GAPDHR2 (5'-TCAAGT CAACCACACGGGTACTGT-3'). Primers were synthesized by MWG Operon (Huntsville, AL).

Reverse transcription-PCR was conducted with $0.2 \mu \mathrm{M}$ of each primer, $30 \mathrm{ng}$ cDNA, $1 \times$ PCR buffer, $2.5 \mathrm{~mm} \mathrm{MgCl}$, $0.2 \mathrm{~mm}$ dNTPs, and $1 \mathrm{U}$ Taq polymerase. For the amplification of PpTFL1 from genomic DNA, reactions were denatured at $94{ }^{\circ} \mathrm{C}$ for $5 \mathrm{~min}$ followed by 45 cycles of $94{ }^{\circ} \mathrm{C}$ for $20 \mathrm{~s}, 65^{\circ} \mathrm{C}$ for $25 \mathrm{~s}, 72{ }^{\circ} \mathrm{C}$ for $3 \mathrm{~min}$, and a final extension at $72{ }^{\circ} \mathrm{C}$ for $5 \mathrm{~min}$. Similar parameters were used for analysis of cDNA, except for the extension time (30 s) and annealing temperatures, which were $66^{\circ} \mathrm{C}$ for PpTFL1 and $60{ }^{\circ} \mathrm{C}$ for $G A P D H$. The number of PCR cycles for cDNA template was 38 and 35, respectively, for PpTFL1 and GAPDH in peach and 32 cycles for PPTFL1 in arabidopsis.

Transformation of arabidopsis with PPTFL1. The arabidopsis actin2 promoter and terminator sequences (An et al., 1996) of vector pACT2 were subcloned into the binary plasmid pCAMBIA1300. The full-length PpTFL1 gene was amplified from peach genomic DNA by PCR and NcoI and ApaI restriction sites were added to the $5^{\prime}$ and $3^{\prime}$ ends, respectively. After confirmation by sequencing, the gene was ligated into cleaved NcoI and ApaI restriction sites located between the AtACT2 regulatory sequences (Fig. 1). The binary plasmid was introduced by heat shock into Agrobacterium tumefaciens EHA105 that was then used to transform arabidopsis (Columbia) by the floral dip method (Clough and Bent, 1998). The resulting seeds were surface-sterilized and selected on agar plates containing half-strength Murashige and Skoog medium and $50 \mathrm{mg} \cdot \mathrm{L}^{-1}$ hygromycin. The plates were kept at $4{ }^{\circ} \mathrm{C}$ for $3 \mathrm{~d}$ and then transferred to a $22{ }^{\circ} \mathrm{C}$ growth room with $16 \mathrm{~h}$ light provided by fluorescent lights $\left(160 \mu \mathrm{mol} \cdot \mathrm{m}^{-2} \cdot \mathrm{s}^{-1}\right)$. Transgenic seedlings and nontransgenic controls were transplanted into soil and allowed to flower in the growth room. The number of rosette leaves produced and the days until flower primordia first became visible were recorded.

IDENTIFICATION AND SEQUENCE COMPARISON OF FT/TFL1 FAMILY MEMBERS. Gene sequences of FT/TFL1 family members in Rosaceae species were obtained from the GenBank database and by screening the draft genomes (v1.0) of peach, apple, and strawberry ( $F$. vesca) (Jung et al., 2008) with orthologous arabidopsis and Vitis vinifera sequences. Multiple sequence alignment was carried out with the predicted protein sequence from peach FT/TFL1 family members and TFL1 of Prunus mume (BAJ14521), M. ×domestica (BAD06418), P. communis (BAD10963), F. vesca (AEP23097), and Rosa chinensis (ADO64261). ClutsalW (Thompson et al., 1994) was used for pairwise alignment with the Gonnet protein weight matrix, a gap penalty of 10 , and gap extension of 0.1 . The multiple sequence alignment output file obtained in FASTA format was subjected to sequence identity and similarities comparison using the software developed at University of Alberta, Canada (Stothard, 2004).

Phylogenetic relationships between FT/TFL1 family members of Rosaceae species were established by maximum likelihood analysis of mRNA sequences using MEGA4 software (Tamura et al., 2007). A total of 1000 bootstraps were performed and bootstrap support values over $50 \%$ are indicated in the results. Predicted mRNA sequences were taken, without adjustment, from the peach genome v1.0, the apple genome v1.0, the strawberry ( $F$. vesca) genome v1.0 (build 8 ), and the 
GenBank database. Sequences from eight species were examined, including 1) P. persica: PpTFL1 (ppa012369m), PpCEN (ppa012343m), PpFT (EU939302), PpBFT (ppa021829m), PpMFT (ppa012388m); 2) M. ×domestica: MdTFL1-1 (AB052994), MdTFL1-2 (AB366643), MdCENa (AB366641), MdCENb (AB366642), MdFT1 (AB161112), MdBFT (MDP0000812208), MdMFT (MDP0000449224); 3) F. vesca: FvTFL1 (mrna30276.1), FvCEN (mrna21992.1), FvFT (mrna21535.1), FvBFT (mrna13304.1), FvMFT (mrna09405.1); 4) P. communis: PcTFL1-1 (AB162042), PcTFL1-2 (AB162048); 5) Pyrus pyrifolia: PpyTFL1-1 (AB601157); 6) Eriobotrya japonica: EjTFL1-1 (AB162045), ElTFL1-2 (AB162051); 7) Cydonia oblonga: CoTFL1-1 (AB162043); and 8) Chaenomeles sinensis: CsTFL1-1 (AB162044).

\section{Results and Discussion}

Pattern of PptFL1 expression in Peach. The expression of PpTFL1 in peach tissues was examined by reverse transcription-PCR (Fig. 2). PpTFL1 transcripts were detected in seedling roots and leaves and young leaves of adult trees, but were not detected in peach embryos, mature leaves, flower buds, and flower petals (Fig. 2A). Detection of a spliced product with primers flanking an intron (Fig. 1) confirmed that PCR products were derived from mRNA, not genomic DNA.

Like PpTFL1, the genes PmTFL1 of japanese apricot $(P$. mume) and MdTFL1-1 of apple are expressed in seedling tissues and young leaves of adult plants (Esumi et al., 2010; Mimida et al., 2009). As a result of its polyploid origin, apple has a second gene, MdTFL1-2, which is expressed in seedling roots and stems but not leaves of seedlings or adult plants. In contrast to PpTFL1 and MdTFL1-2, expression of MdTFL1-1 was observed in flower petals (Mimida et al., 2009).

In peach, flowering is induced starting in late May and the developing floral buds enter dormancy by late summer. After exposure to cool temperatures, bud dormancy is broken in the spring. The final phases of floral development take just before the flowers open, usually in late March to mid-April. PpTFL1 expression in the peach shoot apex was not detected during floral induction, differentiation, or mature floral bud stages

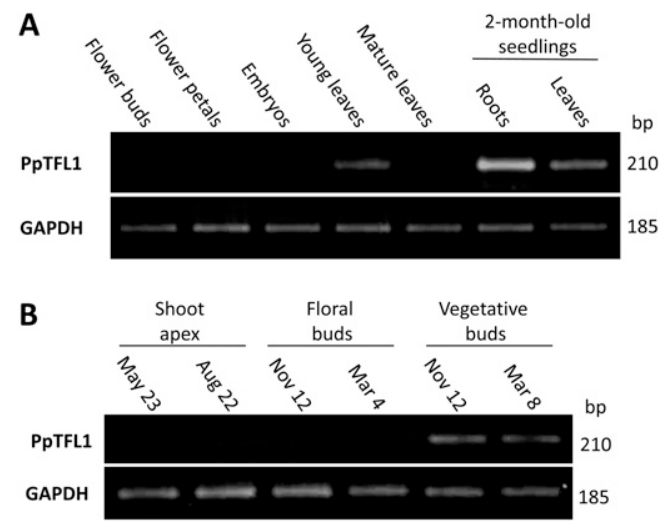

Fig. 2. Expression of PpTFL1 in peach. (A) Reverse transcription-polymerase chain reaction (RT-PCR) analysis of adult and juvenile peach tissue. (B) RTPCR analysis of active and dormant shoot apices at different time points. Glyceraldehyde-3-phosphate dehydrogenase (GAPDH) was used as an internal control for RT-PCR.
(Fig. 2B). PpTFL1, however, was expressed during vegetative bud development.

Similar to peach, TFL1 expression was absent or low during floral differentiation in buds of apple (Hattasch et al., 2008; Mimida et al., 2009, 2011), quince [C. oblonga (Esumi et al., 2008)], and rose [Rosa wichurana (Iwata et al., 2012)]. However, in pear ( $P$. pyrifolia, $P$. communis), one of the two TFL1 genes was expressed during floral differentiation (Esumi et al., 2005, 2008). Like in peach, expression of TFL1 was observed in vegetative buds of japanese apricot (Esumi et al., 2010) and apple (Mimida et al., 2009).

ECTOPIC EXPRESSION OF PPTFL1 In ARABIDOPSIS. To examine the function of $P p T F L 1$, arabidopsis was transformed with the gene construct AtACT2:PpTFL1. Twenty-nine $\mathrm{T}_{1}$ transgenic plants were produced, which varied in flowering time, and four independent transformants with strong phenotypes were characterized further (Fig. 3). The gene construct contained the genomic sequence of PpTFL1, which had to be spliced after transcription in arabidopsis. Reverse transcription-PCR analysis with primers from exons 3 and 4 (Fig. 1) found that the correctly spliced product was present in transgenic plants TC1, TC2, TC7, and TC29 (Fig. 3A). Proper splicing of the entire PpTFL1 transcript to the predicted 574 bp size was observed in TC1 (Fig. 3B) and the other three transgenic lines (not shown).

Constitutive expression of PpTFL1 in arabidopsis prolonged vegetative growth compared with nontransgenic plants, resulting in an increased number of basal rosette leaves. Figure 3D-F shows a range of transgenic phenotypes caused by PpTFL1 expression. Figure $3 \mathrm{~F}$ shows the most severe phenotype, in which 29 rosette leaves were produced before flowering was initiated. The average for this line (TC1) was 21 leaves compared with
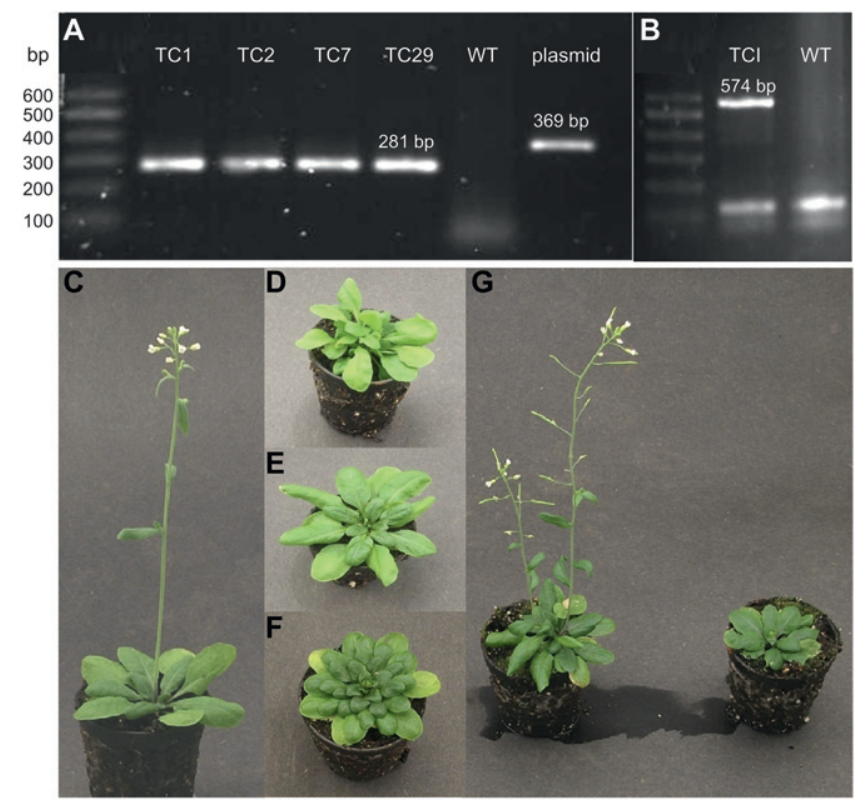

Fig. 3. Expression and phenotype of PpTFL1 in transgenic arabidopsis. (A) Reverse transcription-polymerase chain reaction (RT-PCR) analysis with primers TE3RTF and TE4R of four independent transformants and a wildtype (WT) control. A 369-bp PpTFL1 genomic sequence (plasmid lane) was spliced to a 281-bp product in transgenics. (B) Full-length PpTFL1 transcript amplified with primers TE1F and TE4R in transgenic TC1 but not WT. (C) Nontransgenic flowering phenotype. (D-F) Transgenics with delayed flowering and increased rosette leaf production. (G) Examples of progeny of similar age segregating for delayed flowering phenotype in $\mathrm{T} 2$ generation. 
13 leaves for the control (Table 1). Figure 3G shows an example of segregation of $\mathrm{T}_{2}$ generation plants for the delayed flowering phenotype.

TFL1 transgenes from apple and japanese apricot and were also found to delay flowering in arabidopsis (Esumi et al., 2010; Mimida et al., 2009). Nearly half of the plants transformed with the japanese apricot construct 35S:PmTFL1 exhibited only vegetative growth. Vegetative growth was prolonged by the apple constructs 35S:MdTFL1-1 and 35S 2 : MdTFL1-2. A similar transgenic phenotype was obtained by expression of the close TFL1 relative centroradialis (35S $2: M d C E N \alpha)$. Arabidopsis plants transformed with TFL1-related genes from peach, apricot, and apple showed a range of response; that in japanese apricot (Esumi et al., 2010) was found to correlate with expression levels. This is consistent with the hypothesis that the ratio of FT to TFL1 is a major determinant of floral induction (McGarry and Ayre, 2012).

FT/TFL1 FAMILY IN PEACH AND OTHER ROSACEOUS SPECIES. There are six genes in the arabidopsis FT/TFL1 family (Turck et al., 2008). A search of draft peach genome identified orthologs to five of these genes: TFL1, CEN, FT, BFT (brother of $f t$ ), and MFT (mother of $f t$ and $t f l$ ). A peach gene with similarity to TSF (twin sister of $f t$ ) was not found, similar to BLAST results with apple and strawberry $(F$. vesca) genomes (Mimida et al., 2012). The peach FT/TFL1 family members had a common gene structure with exact conservation of size in two of the four exons (Fig. 4). The deduced amino acid sequence of the five peach genes contained D-P-D-x-P and G-x-H-R motifs, which are conserved in plant FT/TFL1 family members and the phosphatidylethanolamine-binding protein superfamily (Banfield and Brady, 2000).

The predicted protein sequences of peach FT/TFL1 family members were $49 \%$ to $73 \%$ identical (Table 2 ). The five protein sequences were $67 \%$ to $88 \%$ similar when amino acid properties were considered. Sequence identity and similarity was higher between peach genes and their orthologs in other Rosaceae species than among peach FT/TFL1 family members (Table 2; Fig. 5). Phylogenetic analysis identified five distinct clades that corresponded with each of the family members (Fig. 5). A comparison of TFL1 protein sequences of peach, apricot, apple, pear, strawberry ( $F$. vesca), and rose found $88 \%$ to $99 \%$ identity and $91 \%$ to $99 \%$ similarity (Table 2 ). The greatest similarity in TFL1 sequence ( $96 \%$ or greater) was between species of the same subfamily: peach/apricot, apple/pear, and strawberry/rose.

There are numerous species of ornamental value that come from different subfamilies of Rosaceae. Because of the diversification of Rosaceae, multiple reference models may be

Table 1. Phenotype of $\mathrm{T}_{2}$ transgenic arabidopsis plants with PpTFL1 gene.

\begin{tabular}{|c|c|c|c|}
\hline Plant lines & $\begin{array}{c}\text { Time to flowering } \\
{[\text { mean } \pm \text { SE (d)] }}\end{array}$ & $\begin{array}{c}\text { Rosette leaves } \\
{[\text { mean } \pm \text { SE (no.)] }}\end{array}$ & No. \\
\hline WT $(\mathrm{Col})^{\mathrm{z}}$ & $35.4 \pm 1.0$ & $13.2 \pm 0.6$ & 9 \\
\hline \multicolumn{4}{|l|}{ ACT2:PpTFL1 } \\
\hline $\mathrm{TC}^{\mathrm{y}}$ & $39.6 \pm 2.2$ & $21.0 \pm 2.2$ & 10 \\
\hline TC4 & $39.3 \pm 1.6$ & $17.8 \pm 1.0$ & 8 \\
\hline TC7 & $40.6 \pm 2.7$ & $17.8 \pm 1.1$ & 8 \\
\hline TC29 & $39.8 \pm 2.4$ & $17.8 \pm 1.1$ & 8 \\
\hline
\end{tabular}

${ }^{\mathrm{z}}$ Wild-type control (WT) was the arabidopsis Columbia (Col) ecotype. ${ }^{\mathrm{y}}$ Transgenic lines TC1, TC4, TC7, and TC29 contained the terminal flower 1 gene of peach driven by the arabidopsis actin 2 promoter.

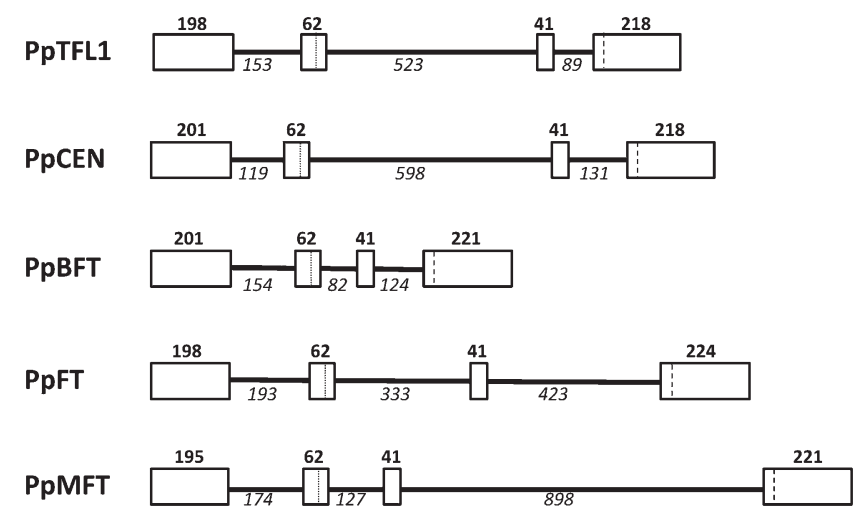

Fig. 4. Peach FT/TFL1 gene family. Exons are shown as boxes with their size in bps above. Sizes of introns (black bars) shown in italics below. Dotted lines in exon 2 indicate location of D-P-D-x-P motif. Dashed lines in exon 4 indicate location of G-X-H-R motif. Gene family members include terminal flower 1 (PpTFL1), centroradialis (PpCEN), flowering locus $T$ (PpFT), brother of $f t$ $(P p B F T)$, and mother of ft and $t f(P p M F T)$.

required for comparative genomics (Shulaev et al., 2008). To examine the reliability of a single genetic model for a conserved function like flowering, peach FT/TFL1 family members can be compared with orthologs in Rosaceae. There is a high degree of sequence conservation between peach FT/TFL1 orthologs and those of other Rosaceae species. The phenotype of transgenic arabidopsis with PpTFL1 was similar to that with PmTFL1, MdTFL1-1, or MdTFL1-2 (Esumi et al., 2010; Mimida et al., 2009). The pattern of expression of TFL1 in peach was closely matched in japanese apricot, but comparison with orthologs in apple and pear was complicated by the expanded genomes of species in the Maloideae subfamily.

Apple and pear have two TFL1 paralogs that exhibited tissue-specific (MdTFL1-2) or developmental (PpyTFL1-1) expression patterns that differed from PpTFL1 and the other paralog. This may be a result of subfunctionalization of the TFL1 paralogs, like in the case of the two apple FT paralogs (Kotoda et al., 2010). The prediction of candidate gene identity and function from peach data may be complicated by the divergence of paralogs. On the other hand, early flowering in pear (P. communis) transformed with citrus FT [Citrus unshiu (Matsuda et al., 2009)] and in plum (Prunus domestica) transformed with poplar FT1 [Populus trichocarpa (Srinivasan et al., 2012)] demonstrates functional conservation between divergent FT genes. Recent studies of TFL1 in F. vesca (Iwata et al., 2012; Koskela et al., 2012) illustrate the potential of this sequenced, herbaceous perennial to contribute to an understanding of the flowering process. For the study of floral genes in woody ornamentals, an advantage of peach is the simplicity of its small, diploid genome in which the floral genes examined to date have been found to be single-copy (An and Li, 2008; Martin et al., 2006; Tadiello et al., 2009; Tani et al., 2009; Xu et al., 2008; Zhang et al., 2008).

An obstacle to the use of peach as a genetic model is the lack of an efficient transformation system for conducting functional genomics. There are alternative approaches being developed for the analysis of genes in peach. Virus-induced gene silencing (VIGS) is being investigated in peach and apricot using apple latent spherical virus (ALSV) vectors (Kawai et al., 2012). An ALSV vector containing an MdTFL1-1 fragment was able to induce early flowering in apple through VIGS (Sasaki et al., 
Table 2. Sequence comparison of FT/TFL family protein sequences of Prunus persica and TFL1 proteins of other Rosaceae species. ${ }^{\mathrm{z}}$

\begin{tabular}{|c|c|c|c|c|c|c|c|c|c|c|}
\hline & \multicolumn{5}{|c|}{ FT/TFL1 family orthologs in peach } & \multicolumn{5}{|c|}{ TFL1 orthologs in other Rosaceae species } \\
\hline & TFL1 & FT & BFT & MFT & CEN & $\mathrm{Pm}$ & $\mathrm{Md}^{\mathrm{y}}$ & $\mathrm{Pc}^{\mathrm{x}}$ & $\mathrm{FV}$ & $\mathrm{Rc}$ \\
\hline PpTFL1 & - & $59 / 74$ & $67 / 81$ & $51 / 67$ & $73 / 88$ & 98/98 & $88 / 92$ & $89 / 93$ & $88 / 95$ & $89 / 92$ \\
\hline PpFT & & - & $59 / 76$ & $52 / 69$ & $60 / 76$ & $60 / 74$ & $59 / 74$ & $58 / 69$ & $60 / 73$ & $59 / 69$ \\
\hline PpMFT & & & & - & $54 / 69$ & $52 / 68$ & $51 / 69$ & $51 / 66$ & $53 / 68$ & $53 / 67$ \\
\hline PpCEN & & & & & - & $75 / 90$ & $73 / 86$ & $75 / 85$ & $78 / 90$ & $77 / 86$ \\
\hline PmTFL1 & & & & & & - & $89 / 93$ & $89 / 93$ & $89 / 96$ & $89 / 93$ \\
\hline PcTFL1-1 & & & & & & & & - & $89 / 94$ & $89 / 92$ \\
\hline FvTFL1 & & & & & & & & & - & $92 / 96$ \\
\hline RcTFL1 & & & & & & & & & & \\
\hline
\end{tabular}

RcTFL1

${ }^{\mathrm{z}}$ The percent identity/similarity among terminal flower 1 (TFL1), flowering locus T (FT), brother of ft (BFT), mother of ft and tfl1 (MFT), and centroradialis (CEN) protein sequences is presented. The species examined include Prunus mume (Pm), Malus $\times$ domestica (Md), Pyrus communis $(\mathrm{Pc})$, Fragaria vesca $(\mathrm{Fv})$, and Rosa chinensis $(\mathrm{Rc})$.

${ }^{\mathrm{y}} \mathrm{MdTFL} 1-1$.

xPCTFL1-1.

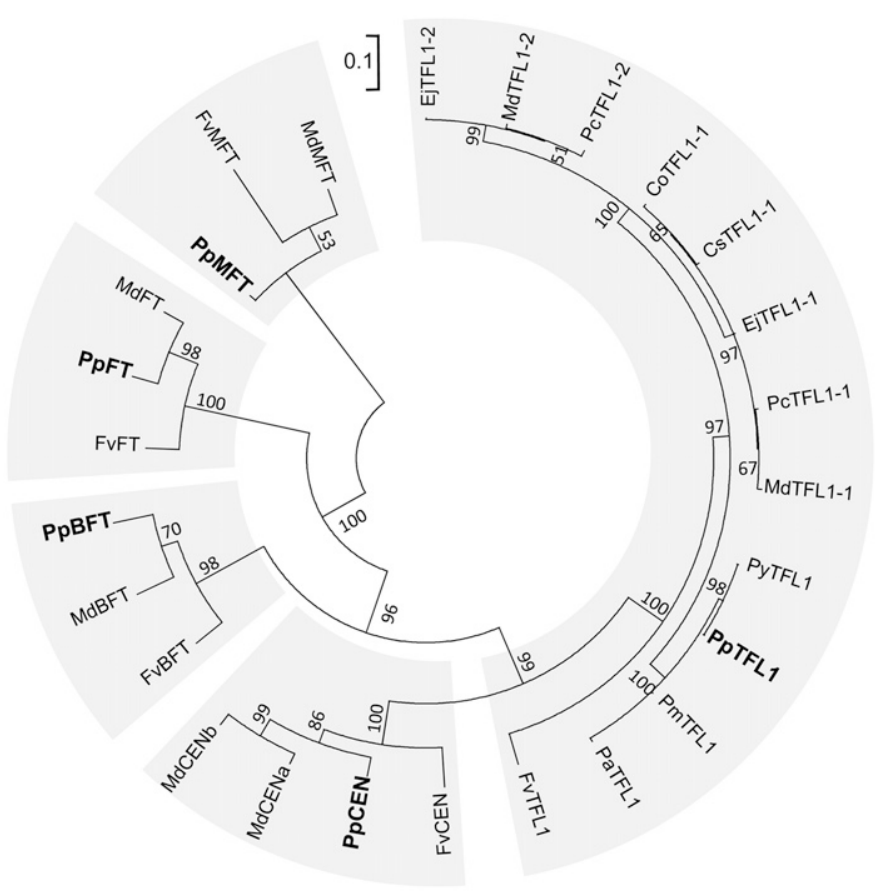

Fig. 5. Phylogenetic analysis of FT/TFL1 family members of Rosaceae species. The phylogenetic relationships were established by maximum likelihood analysis of mRNA sequences with peach sequences shown in bold. A total 1000 bootstraps were performed and bootstrap support values over $50 \%$ are shown. Five clades were identified (gray shading) that corresponded to different FT/TFL1 family members. Scale bar units for branch length are 0.1 substitutions/site. The species examined include Prunus persica (Pp), Prunus mume $(\mathrm{Pm})$, Malus $\times$ domestica $(\mathrm{Md})$, Pyrus communis $(\mathrm{Pc})$, Fragaria vesca (Fv), Pyrus pyrifolia (Ppy), Eriobotrya japonica (Ej), Cydonia oblonga (Co), and Chaenomeles sinensis (Cs).

2011). Viruses have also been used to deliver gene-specific nucleases for targeted mutation (Marton et al., 2010). TILLING is another functional genomics strategy (Wang et al., 2012) that can be applied to peach, and an EMS-mutagenized peach TILLING population is being established (V. Decroocq, personal communication). These techniques could allow the genetic control of floral induction to be examined in peach for application to other woody ornamentals.

\section{Literature Cited}

An, L. and T. Li. 2008. Cloning, expression, and production of polyclonal antibodies of peach $P p L F Y$. Acta Hort. Sinica 35:15731580.

An, Y.-Q., J.M. McDowell, S. Huang, E.C. McKinney, S. Chambliss, and R.B. Meagher. 1996. Strong, constitutive expression of the Arabidopsis ACT2/ACT8 actin subclass in vegetative tissues. Plant J. 10:107-121.

Angel, A., J. Song, C. Dean, and M. Howard. 2011. A Polycomb-based switch underlying quantitative epigenetic memory. Nature 476:105108.

Arús, P., I. Verde, B. Sosinski, T. Zhebentyayeva, and A.G. Abbott. 2012. The peach genome. Tree Genet. Genomes 8:531-547.

Banfield, M.J. and R.L. Brady. 2000. The structure of Antirrhinum centroradialis protein (CEN) suggests a role as a kinase regulator. J. Mol. Biol. 297:1159-1170.

Benlloch, R., A. Berbel, A. Serrano-Mislata, and F. Madueno. 2007. Floral initiation and inflorescence architecture: A comparative view. Ann. Bot. (Lond.) 100:659-676.

Chen, Y., S. Weining, and G. Daggard. 2003. Preparation of total RNA from a very small wheat embryo suitable for differential display. Ann. Appl. Biol. 143:261-264.

Chen, Y. and H.D. Wilde. 2011. Mutation scanning of peach floral genes. BMC Plant Biol. 11:96.

Clough, S.J. and A.F. Bent. 1998. Floral dip: A simplified method for Agrobacterium-mediated transformation of Arabidopsis thaliana. Plant J. 16:735-743.

Esumi, T., Y. Kitamura, C. Hagihara, H. Yamane, and R. Tao. 2010. Identification of a TFL1 ortholog in japanese apricot (Prunus mume Sieb. et Zucc.). Sci. Hort. 25:608-616.

Esumi, T., R. Tao, and K. Yonemori. 2005. Isolation of LEAFY and TERMINAL FLOWER1 homologues from six fruit tree species in the subfamily Maloideae of the Rosaceae. Sex. Plant Reprod. 17:277-287.

Esumi, T., R. Tao, and K. Yonemori. 2008. Expression analysis of the LFY and TFL1 homologs of japanese pear (Pyrus pyrifolia Nakai) and quince (Cydonia oblonga Mill.). J. Jpn. Soc. Hort. Sci. 77:128-136.

Frieman, A., L. Shlizerman, S. Golobovitch, Z. Yablovitz, R. Korchinsky, Y. Cohen, A. Samach, E. Chevreau, P.-M. Le Roux, A. Patocchi, and M.A. Flaishman. 2011. Development of a transgenic early flowering pear (Pyrus communis L.) genotype by RNAi silencing of PcTFL1-1 and PCTFL1-2. Planta 235:1239-1251.

Hanano, S. and K. Goto. 2011. Arabidopsis TERMINAL FLOWERI is involved in the regulation of flowering time and inflorescence development through transcriptional repression. Plant Cell 23:31723184 . 
Hanzawa, Y., T. Money, and D. Bradley. 2005. A single amino acid converts a repressor to an activator of flowering. Proc. Natl. Acad. Sci. USA 102:7748-7753.

Hattasch, C., H. Flachowsky, D. Kapturska, and M.V. Hanke. 2008. Isolation of flowering genes and seasonal changes in their transcript levels related to flower induction and initiation in apple (Malus domestica). Tree Physiol. 28:1459-1466.

Iwata, H., A. Gaston, A. Remay, T. Thouroude, J. Jeauffre, K. Kawamura, L. Hibrand-Saint Oyant, T. Araki, B. Denoyes, and F. Foucher. 2012. The TFL1 homologue KSN is a regulator of continuous flowering in rose and strawberry. Plant J. 69:116-125.

Jung, S., M. Staton, T. Lee, A. Blenda, R. Svancara, A. Abbott, and D. Main. 2008. Genomic, genetic, and breeding resources for Rosaceae crop improvement. 1 Oct. 2012. <http://www.rosaceae.org/>.

Kawai, T., E. Nagayama, T. Akagi, and R. Tao. 2012. Plant and Animal Genome XX. 1 Oct. 2012. <https://pag.confex.com/pag/xx/ webprogram/Paper2992.html>.

Koskela, E.A., K. Mouhu, M.C. Albani, T. Kurokura, M. Rantanen, D.J. Sargent, N.H. Battey, G. Coupland, P. Elomaa, and T. Hytönen. 2012. Mutation in TERMINAL FLOWER1 reverses the photoperiodic requirement for flowering in the wild strawberry Fragaria vesca. Plant Physiol. 159:1043-1054.

Kotoda, N., H. Hayashi, M. Suzuki, M. Igarashi, Y. Hatsuyama, S. Kidou, T. Igasaki, M. Nishiguchi, K. Yano, T. Shimizu, S. Takahashi, H. Iwanami, S. Moriya, and K. Abe. 2010. Molecular characterization of FLOWERING LOCUS T-like genes of apple (Malus $\times$ domestica Borkh.). Plant Cell Physiol. 51:561-575.

Kotoda, N., H. Iwanami, S. Takahashi, and K. Abe. 2006. Antisense expression of MdTFL1, a TFL1-like gene, reduces the juvenile phase in apple. J. Amer. Soc. Hort. Sci. 131:74-81.

Liang, H., T. Zhebentyayevaa, B. Olukolua, D. Wilde, G.L. Reighard, and A. Abbott. 2010. Comparison of gene order in the chromosome region containing a TERMINAL FLOWER 1 homolog in apricot and peach reveals microsynteny across angiosperms. Plant Sci. 179:390-398.

Martin, T., M. Hu, H. Labbe, S. McHugh, A. Svircev, and B. Miki. 2006. PpAG1, a homolog of AGAMOUS, expressed in developing peach flowers and fruit. Can. J. Bot. 84:767-776.

Marton, I., A. Zuker, E. Shklarman, V. Zeevi, A. Tovkach, S. Roffe, M. Ovadis, T. Tzfira, and A. Vainstein. 2010. Nontransgenic genome modification in plant cells. Plant Physiol. 154:1079-1087.

Matsuda, N., K. Ikeda, M. Kurosaka, T. Takashina, K. Isuzugawa, T. Endo, and M. Omura. 2009. Early flowering phenotype in transgenic pears (Pyrus communis L.) expressing the CiFT gene. J. Jpn. Soc. Hort. Sci. 78:410-416.

McGarry, R.C. and B.G. Ayre. 2012. Manipulating plant architecture with members of the CETS gene family. Plant Sci. 188/189:71-81.

Mimida, N., N. Kotoda, T. Ueda, M. Igarashi, Y. Hatsuyama, H. Iwanami, S. Moriya, and K. Abe. 2009. Four TFL1/CEN-like genes on distinct linkage groups show different expression patterns to regulate vegetative and reproductive development in apple (Malus $\times$ domestica Borkh.). Plant Cell Physiol. 50:394-412.

Mimida, N., J. Li, C. Zhang, S. Moriya, Y. Moriya-Tanaka, H. Iwanami, C. Honda, H. Oshino, K. Takagishi, A. Suzuki, S. Komori, and M. Wada. 2012. Divergence of TERMINAL FLOWERl-like genes in Rosaceae. Biol. Plant. 56:465-472.

Mimida, N., A. Ureshino, N. Tanaka, N. Shigeta, N. Sato, Y. MoriyaTanaka, H. Iwanami, C. Honda, A. Suzuki, S. Komori, and M. Wada. 2011. Expression patterns of several floral genes during flower initiation in the apical buds of apple (Malus domestica Borkh.) revealed by in situ hybridization. Plant Cell Rep. 30:1485-1492.

Mohamed, R., C.-T. Wang, C. Ma, O. Shevchenko, S.J. Dye, J.R. Puzey, E. Etherington, X. Sheng, R. Meilan, S.H. Strauss, and A.M. Brunner. 2010. Populus CEN/TFL1 regulates first onset of flowering, axillary meristem identity and dormancy release in Populus. Plant $\mathrm{J}$ 62:674-688.

Pnueli, L., L. Carmel-Goren, D. Hareven, T. Gutfinger, J. Alvarez, M. Gana, D. Zamir, and E. Lifschitz. 1998. The SELF-PRUNING gene of tomato regulates vegetative to reproductive switching of sympodial meristems and is the ortholog of CEN and TFL1. Development 125:1979-1989.

Sasaki, S., N. Yamagishi, and N. Yoshikawa. 2011. Efficient virusinduced gene silencing in apple, pear and Japanese pear using Apple latent spherical virus vectors. Plant Methods 7:15.

Shulaev, V., S.S. Korban, B. Sosinski, A.G. Abbott, H.S. Aldwinckle, K.M. Folta, A. Iezzoni, D. Main, P. Arús, A.M. Dandekar, K. Lewers, S.K. Brown, T.M. Davis, S.E. Gardiner, D. Potter, and R.E. Veilleux. 2008. Multiple models for Rosaceae genomics. Plant Physiol. 147:985-1003.

Srinivasan, C., C. Dardick, A. Callahan, and R. Scorza. 2012. Plum (Prunus domestica) trees transformed with poplar FT1 result in altered architecture, dormancy requirement, and continuous flowering. PLoS ONE 7:e40715.

Stothard, P. 2004. The sequence manipulation suite. 1 Oct. 2012. $<$ http://www.ualberta.ca/ stothard/javascript/ident_sim.html $>$.

Tadiello, A., A. Pavanello, D. Zanin, E. Caporali, L. Colombo, G.L. Rotino, L. Trainotti, and G. Casadoro. 2009. A PLENA-like gene of peach is involved in carpel formation and subsequent transformation into a fleshy fruit. J. Expt. Bot. 60:651-661.

Tamura, K., J. Dudley, M. Nei, and S. Kumar. 2007. MEGA4: Molecular evolutionary genetics analysis (MEGA) software version 4.0. Mol. Biol. Evol. 24:1596-1599.

Tani, E., A.N. Polidoros, E. Flemetakis, C. Stedel, C. Kalloniati, K. Demetriou, P. Katinakis, and A.S. Tsaftaris. 2009. Characterization and expression analysis of AGAMOUS-like, SEEDSTICK-like, and SEPALLATA-like MADS-box genes in peach (Prunus persica) fruit. Plant Physiol. Biochem. 47:690-700.

Thompson, J.D., D.G. Higgins, and T.J. Gibson. 1994. CLUSTAL W: Improving the sensitivity of progressive multiple sequence alignment through sequence weighting, position-specific gap penalties and weight matrix choice. Nucleic Acids Res. 22:4673-4680.

Tian, Z., X. Wang, R. Lee, Y. Lib, J.E. Specht, R.L. Nelson, P.E. McClean, L. Qiub, and J. Ma. 2010. Artificial selection for determinate growth habit in soybean. Proc. Natl. Acad. Sci. USA 107:8563-8568.

Tong, Z., Z. Gao, F. Wang, J. Zhou, and Z. Zhang. 2009. Selection of reliable reference genes for gene expression studies in peach using real-time PCR. BMC Mol. Biol. 10:71.

Turck, F., F. Fornara, and G. Coupland. 2008. Regulation and identity of florigen: FLOWERING LOCUS T moves center stage. Annu. Rev. Plant Biol. 59:573-594.

Wang, J.W., M.Y. Park, L.J. Wang, Y. Koo, X.Y. Chen, D. Weigel, and R.S. Poethig. 2011a. miRNA control of vegetative phase change in trees. PLoS Genet. 7:e1002012.

Wang, L.-N., Y.-F. Liu, Y.-M. Zhang, R.-X. Fang, and Q.-L. Liu. 2011 b. The expression level of Rosa Terminal Flower 1 (RTFL1) is related with recurrent flowering in roses. Mol. Biol. Rep. 39:3737-3746.

Wang, T.L., C. Uauy, F. Robson, and B. Till. 2012. TILLING in extremis. Plant Biotechnol. J. 10:761-772.

Wilkie, J.D., M. Sedgley, and T. Olesen. 2008. Regulation of floral initiation in horticultural trees. J. Expt. Bot. 59:3215-3228.

Woodworth, C.M. 1932. Genetics and breeding in the improvement of the soybean. Illinois Agr. Expt. Sta. Bul. 384:297-404.

Xu, Y., L. Zhang, H. Xie, Y.-Q. Zhang, M.M. Oliveira, and R.-C. Ma. 2008. Expression analysis and genetic mapping of three SEPALLATAlike genes from peach [Prunus persica (L.) Batsch]. Tree Genet. Genomes 4:693-703.

Yaish, M.W., J. Colasanti, and S.J. Rothstein. 2011. The role of epigenetic processes in controlling flowering time in plants exposed to stress. J. Expt. Bot. 62:3727-3735.

Yamane, H., T. Ooka, H. Jotatsu, R. Sasaki, and R. Tao. 2011. Expression analysis of PpDAM5 and PpDAM6 during flower bud development in peach (Prunus persica). Sci. Hort. 129:844-848.

Yeager, A.F. 1927. Determinate growth in the tomato. J. Hered. 18:263-265.

Zhang, L., Y. Xu, and R. Ma. 2008. Molecular cloning, identification, and chromosomal localization of two MADS box genes in peach (Prunus persica). J. Genet. Genomics 35:365-372. 